\title{
Exposure to oxychlordane is associated with shorter telomeres in arctic breeding kittiwakes
}

Pierre Blévin ${ }^{1 *}$, Frédéric Angelier ${ }^{1}$, Sabrina Tartu $^{1}$, Stéphanie Ruault ${ }^{1}$, Paco Bustamante ${ }^{2}$, Dorte Herzke $^{3}$, Børge Moe ${ }^{4}$, Claus Bech ${ }^{5}$, Geir W. Gabrielsen ${ }^{6}$, Jan Ove Bustnes ${ }^{4}$, Olivier Chastel $^{1}$

${ }^{1}$ Centre d'Etudes Biologiques de Chizé (CEBC), UMR 7372 CNRS-Université de la Rochelle, 79360 Villiers-en-Bois, France

${ }^{2}$ Littoral Environnement et Sociétés (LIENSs), UMR 7266 CNRS-Université de la Rochelle, 17000 La Rochelle, France

${ }^{3}$ Norwegian Institute for Air Research, NILU, Fram centre, NO-9296 Troms $\varnothing$, Norway

${ }^{4}$ Norwegian Institute for Nature Research, NINA, Fram centre, NO-9296 Troms $\varnothing$, Norway

${ }^{5}$ Department of Biology, Norwegian University of Science and Technology, 7491 Trondheim, Norway

${ }^{6}$ Norwegian Polar Research Institute, Fram centre, NO-9296 Troms $\varnothing$, Norway

Corresponding author : Pierre Blévin

Centre d'Etudes Biologiques de Chizé

CNRS UMR 7266

79360 Villiers-en-Bois, France

*pierre.blevin@cebc.cnrs.fr 
Abstract: Telomeres are DNA-protein complexes located at the end of chromosomes, which play an important role in maintaining the genomic integrity. Telomeres shorten at each cell division and previous studies have shown that telomere length is related to health and lifespan and can be affected by a wide range of environmental factors. Among them, some persistent organic pollutants (POPs) have the potential to damage DNA. However, the effect of POPs on telomeres is poorly known for wildlife. Here, we investigated the relationships between some legacy POPs (organochlorine pesticides and polychlorobiphenyls) and telomere length in breeding adult blacklegged kittiwakes (Rissa tridactyla), an arctic seabird species. Our results show that among legacy POPs, only blood concentration of oxychlordane, the major metabolite of chlordane mixture, is associated with shorter telomere length in females but not in males. This suggests that female kittiwakes could be more sensitive to oxychlordane, potentially explaining the previously reported lower survival rate in most oxychlordane contaminated kittiwakes from the same population. This study is the first to report a significant and negative relationship between POPs and telomere length in a free-living bird and highlights sex-related susceptibility to banned pesticides.

Keywords: Seabirds; Svalbard; Contaminants Organochlorines; PCBs; DNA 


\section{Introduction}

Telomeres are DNA-protein complexes located at the end of linear chromosomes which play a critical role in maintaining the genomic integrity (Blackburn, 1991; Monaghan and Haussmann, 2006). The DNA polymerase protein complex cannot replicate the very ends of chromosomes during mitosis, and, consequently telomeres shorten at each cell division (Olovnikov, 1996). When telomeres reach a critical lower threshold, cell division can damage coding DNA leading to apoptosis or replicative senescence (Olovnikov, 1996; Campisi et al., 2001). It was originally thought that telomere loss occurred at a constant rate in individuals through their life, and telomere length could therefore act as an internal 'mitotic clock' to measure the chronological age of organisms into the wild (Haussmann and Vleck, 2002). However, recent studies have shown that telomere length predicts survival (Haussmann et al., 2005; Bize et al., 2009; Salomons et al., 2009; Heidinger et al., 2012; Angelier et al., 2013; Barrett et al., 2013) and is related to a wide range of environmental stressors (Mizutani et al., 2013; Meillère et al., 2015). Consequently, telomere length is considered as more related to biological age than chronological age per se (Monaghan and Haussmann, 2006; Barrett et al., 2013).

In humans, telomere erosion can be accelerated by different environmental factors such as exposure to pollutants (Zhang et al., 2013). For instance, it has been reported that outdoor workers exposed to traffic pollution have shorter telomeres than indoor office workers (Hoxha et al., 2009). Similarly, women telomere length decreases as exposure to pollution caused by hazardous wastes increases (De Felice et al., 2012). One underlying mechanism that could potentially explain accelerated telomere shortening is oxidative stress (Von Zglinicki et al., 2000; Zhang et al., 2013). This corresponds to the imbalance between the production of reactive oxygen species (ROS) and the antioxidant capacity of an organism (Finkel and Holbrook, 2000). When metabolic by-products, such as ROS, are not fully neutralized by anti-oxidant defenses, they may oxidize cellular macromolecules such as DNA (Houben et al., 2008). Hence, 
telomere length may partly reflect oxidative stress history of an individual (Houben et al., 2008). Among contaminants, some persistent organic pollutants (POPs) have the potential to damage DNA by triggering oxidative stress and even decrease survival (Fernie et al., 2005; Isaksson, 2010; Letcher et al., 2010; Erikstad et al., 2013; Costantini et al., 2014; Sletten et al., 2016). However, the effect of POPs on telomere length is poorly known for wildlife. To the best of our knowledge, only one study has addressed this topic in a free-living animal with low contamination levels but failed to find any significant relationships (Sletten et al., 2016).

Due to their high volatility and persistence in time, POPs reach remote areas such as the Arctic (Gabrielsen and Henriksen, 2001). Once deposited in marine ecosystems, living organisms assimilate the POPs via food intake. The POP concentrations then increase from the marine environment into the organisms and throughout food webs due to bioaccumulation and biomagnification (Letcher et al., 2010). Seabirds are top predators; consequently, they are particularly exposed to POPs contamination. They therefore appear as highly relevant biological models to investigate the influence of POPs on telomere length. A previous study in a Svalbard population of black-legged kittiwakes Rissa tridactyla ("kittiwakes" hereafter) has reported high oxidative stress levels in most POPs contaminated individuals (POPs included polychlorobiphenyls: PCBs and one organochlorine pesticide: OCP; Lindsøe, 2012). Additionally, adult survival rate in the same population of kittiwakes was negatively linked to some OCPs (Goutte et al., 2015). In this study, we investigated the relationships between some legacy POPs (OCPs and PCBs) and telomere length in Svalbard kittiwakes. Because telomere length is classically reduced in response to oxidative stress (Von Zglinicki et al., 2000; Zhang et al., 2013) and often tightly linked to survival (Haussmann et al., 2005; Bize et al., 2009; Salomons et al., 2009; Heidinger et al., 2012; Angelier et al., 2013; Barrett et al., 2013), we predicted that POP levels would be negatively related to telomere length. 


\section{Materials and methods}

\subsection{Study area and sampling collection}

Fieldwork was carried out in 2012 from July $12^{\text {th }}$ to July $27^{\text {th }}$ in Krykkjefjellet colony of Kongsfjorden, Svalbard, (78 $\left.54^{\prime} N, 12^{\circ} 13^{\prime} E\right)$, Svalbard. A total of 38 individuals (22 males and 16 females) were caught on their nest with a noose at the end of a 5mfishing rod during the chick rearing period. At capture, a $2 \mathrm{~mL}$ blood sample was collected from the alar vein using a heparinized syringe and a $25 \mathrm{G}$ needle to determine legacy POP levels, telomere length and the sex of individuals. Blood samples were stored at $-20{ }^{\circ} \mathrm{C}$ until subsequent analyses. The sex of individuals was determined from red blood cells by polymerase chain reaction (PCR) at the Centre d'Etudes Biologiques de Chizé (CEBC) as previously described (Weimerskirch et al., 2005).

\subsection{Telomere assay}

Telomere length was determined at the CEBC by Southern blot using the TeloTAGGG Telomere Length Assay (Roche, Mannheim, Germany) as previously described and with minor modifications (Foote et al., 2010; Kimura et al., 2010). Telomere length analysis has already been successfully achieved on the same population of Svalbard kittiwakes (Schultner et al., 2014a). Briefly, samples were digested with proteinase K, and DNA was extracted from red blood cells by using the DNeasy blood and tissue kit (Qiagen). DNA quality was checked by gel electrophoresis and optical density spectrophotometry. Preliminary tests have been conducted to determine the optimal amount of DNA to be used and, for each sample, $0.7 \mu \mathrm{g}$ of DNA was digested with the restriction enzymes HinfI and RsaI for $16 \mathrm{~h}$ at $37{ }^{\circ} \mathrm{C}$. Digested DNA samples were then separated using a pulse-field gel electrophoresis (Bio-Rad) on a $0.8 \%$ agarose gel. All samples were run in four gels. Samples were randomly assigned to a gel. Internal controls were run on each gel to measure inter-gel variations. The gels were run at 3.0 
$\mathrm{V} / \mathrm{cm}$ with an initial switch time of $0.5 \mathrm{~s}$ to a final switch time of $7 \mathrm{~s}$ for $14 \mathrm{~h}$. Following that step, the gel was depurinated and denaturated in an alkaline solution. The gel was then neutralized and DNA was transferred onto a nitrocellulose membrane by Southern blot (Hybond $\mathrm{N}+$, Amersham Life Science, Amersham, UK). The membrane was incubated at $120^{\circ} \mathrm{C}$ for 20 min in order to fix the DNA. The DNA was then hybridized with a digoxigenin-labeled probe specific for telomeric sequences and incubated with antidigoxigenin-specific antibody before visualization with a Chemidoc (Bio Rad). Telomere length was then analyzed using ImageJ to extract telomere smear densities. Lane-specific background was subtracted from each density value and telomere length (mean value) was then calculated using a window of 5-30 kb that includes the whole smear (Nussey et al., 2014). Inter-gel CV was $1.40 \%$.

\subsection{POPs analyses}

POPs were analyzed from whole blood at the Norwegian Institute for Air Research (NILU) in Troms $\emptyset$, Norway. Only compounds that potentially affect survival of kittiwakes were considered in this study (Goutte et al. 2015). Thus, we selected the $\sum$ PCBs (CB-99, -118, -138, $-153,-180,-183$ and -187 ), and the OCPs (HCB, p,p'-DDE, oxychlordane, trans- and cisnonachlor). To a blood total sample of 0.5 to $1.5 \mathrm{~mL}$, a $100 \mu \mathrm{L}$ internal standard solution was added $\left({ }^{13} \mathrm{C}\right.$-labeled compounds from Cambridge Isotope Laboratories: Woburn, MA, USA). The sample was extracted twice with $6 \mathrm{~mL}$ of n-hexane, after denaturation with ethanol and a saturated solution of ammonium sulphate in water. Matrix removal on florisil columns, separation on an Agilent Technology 7890 GC and detection on an Agilent Technology 5975CMSDwere performed as previously described (Herzke et al., 2009). For validation of the results, blanks (clean and empty glass tubes treated like a sample, 3 in total) were run for every 10 samples, while standard reference material ( 3 in total, 1589a human serum from NIST) was run for every 10 samples. The accuracy of the method was within the 70 and $108 \%$ range. 


\subsection{Statistical analyses}

Statistical tests were performed using R 2.13.1 (R Development Core Team, 2011).We first checked if telomere length and POP levels differed between sexes using the parametrical test of Welch. The influence of POPs' contamination on telomere length was investigated with Linear Models. Thus, $\Sigma$ POPs, $\Sigma$ PCBs, HCB, $p, p^{\prime}$-DDE, oxychlordane, cis- and trans-nonachlor were defined as independent variables and telomere length as the dependent variable. Because blood contaminant concentrations differed between males and females (see Results), including the factor "sex" and the variable "IPOPs" in the same model could lead to multicollinearity problems and biased results (Graham, 2003). Additionally, it is now well established that males and females can react in different way to environmental stressors such as POPs contamination. Specifically, previous studies conducted on kittiwakes from Krykkjefjellet colony have reported sex differences regarding body condition, hormones levels, endocrine disruptions, phenology, breeding decision and even survival rate (Goutte et al., 2010, 2015; Schultner et al., 2014b; Tartu et al., 2013, 2014, 2015a). Therefore, male and female kittiwakes were separated in statistical analyses. Diagnostic plots were assessed and Shapiro normality tests were performed on residuals to test whether data sufficiently met the assumption of the linear model. Multiple testing can potentially lead to misleading results, indicating statistical significance in situations where there is none. Consequently, we performed bootstrapping (i.e. resampling method) from the data sets of significant relationship and then assessed diagnostic plot to corroborate the results (see Supplementary materials; Chernick and Labudde, 2014). A significance level of $\alpha<0.05$ was used for all tests.

\section{Results}

Telomere length was not related to sex $(\mathrm{t}=-1.438$, P-value $=0.160)$ and $\Sigma$ POPs tended to be higher in male than in female kittiwakes $(\mathrm{t}=-1.976, \mathrm{P}$-value $=0.056) . \Sigma \mathrm{POPs}, \Sigma \mathrm{PCBs}, \mathrm{HCB}$, 
$p, p^{\prime}$-DDE, cis- and trans-nonachlor were not related to telomere length in male nor in female kittiwakes (All P-values $\geq 0.259$; Table 1). In females, we found a significant and negative association between oxychlordane and telomere length (Table 1; Fig. 1a). However, we found no relationship between oxychlordane and telomere length in males (Table 1; Fig. 1b).

\section{Discussion}

Our results on adult kittiwakes showed that among legacy POPs, only blood concentrations of oxychlordane were negatively associated with telomere length in females but not in males. Oxychlordane and chlordane mixture have already been associated with lower survival in both males and females from the same kittiwake population (Goutte et al., 2015). Our study reports a negative relationship between telomere length only in females, thus providing a possible mechanism linking oxychlordane exposure and female mortality. Regarding males, it is thus likely that oxychlordane exposure may lead to a lower survival rate in another way, independent of telomere attrition. Effects of contaminants on telomere length are still poorly known; most of the studies have focused on humans (Zhang et al., 2013) and to the best of our knowledge, only one study has investigated the relationships between POPs and telomere length in wildlife (Sletten et al., 2016).

So far, 11 of the 14 studies investigating the relationship between telomere length and environmental and occupational chemical exposure in humans, have reported significant negative associations (Rigolin et al., 2004; Hoxha et al., 2009; Bin et al., 2010; McCracken et al., 2010; Pavanello et al., 2010; Li et al., 2011; Rollison et al., 2011; De Felice et al., 2012; Eshkoor et al., 2012; Hou et al., 2012; Wu et al., 2012). For example, shorter telomeres were associated with pesticide exposure in patients with myelodysplastic syndrome (Rigolin et al., 2004; Rollison et al., 2011). Similarly, a study conducted in an apparent healthy Korean population reported a negative association between telomere length and exposure to high levels 
of POPs, including OCPs ( $p, p^{\prime}$-DDE, trans-nonachlor and oxychlordane), PCBs and polybrominated diphenylethers (Shin et al., 2010). The only study investigating relationships between telomere length and contamination in wildlife has been performed on white-tailed eagle (Haliaeetus albicilla) chicks in northern Norway (Sletten et al., 2016). In this study, the authors did not find any relationship between telomere length and POPs, including OCPs, PCBs and perfluorinated compounds. However, the relatively low levels of contaminants in whitetailed eagle chicks compared to those measured in adult kittiwakes may explain the discrepancy in the results. Oxychlordane concentrations in kittiwakes measured in the present study (4019 $\pm 1315 \mathrm{pg} / \mathrm{g} \mathrm{ww}$ ) were on average, around 3 times higher than those reported for eagle chicks $(1483 \pm 197 \mathrm{pg} / \mathrm{gww})$.With this exception, our results are thus consistent with previous works and suggest a negative effect of oxychlordane on telomere length in kittiwakes.

Surprisingly, the relationships between oxychlordane and telomere length were sex dependent and a significant relationship was found in females, but not in males. How to explain such a difference? There are some indications that female seabirds may be more sensitive to high levels of OCPs than males. In glaucous gulls (Larus hyperboreus) and in kittiwakes, OCPs exposure mostly affected survival rate in females (Erikstad et al., 2013; Goutte et al., 2015). Furthermore, in wandering albatrosses (Diomedea exulans), another long-lived seabird species, the relationships between POP levels and oxidative stress were dependent of reproductive effort and breeding females had the highest levels of haptoglobin, a well-known acute phase protein that indicates an ongoing inflammatory response which can limit the spread of oxidative damages, compared to breeding males (Costantini et al., 2014). Thus, the influence of contaminants on oxidative stress may be exacerbated by reproductive effort. Although kittiwakes are considered to share equally incubation and chick rearing duties (Coulson, 2011), egg production represents a significant and important cost for females (Monaghan and Nager, 1997). It is thus possible that the cost of egg production increases the sensitivity of female 
kittiwakes to oxychlordane. This may therefore explain the sex-dependent relationship between telomere length and oxychlordane burden. Furthermore, although female birds transfer a significant part of their PCBs and DDT burden to their eggs, oxychlordane on the other hand, seemed to be more selectively retained by the female, at least in female glaucous gulls (Verboven et al., 2009). In female kittiwakes, it is thus possible that the energetic cost of clutch production added to the maintenance of significant oxychlordane levels would exacerbate the toxic effects of this chlorinated pesticide.

Our study was conducted on breeding adults (i.e. at least 3-4 years old; Coulson, 2011). However, the birds' age was unknown in our study, thus a possible confounding factor could be that birds with high levels of OCPs are the oldest birds with the shortest telomeres. If so, the negative relationship between oxychlordane and telomere length would be induced by the age of individuals rather by a direct effect of oxychlordane on telomere attrition. Although several studies suggested a negative effect of age on telomere length (Haussmann and Vleck, 2002; Haussmann et al., 2003), other reported that telomere loss mainly occurs early in life of longlived seabird (i.e. between chick and adult stage) rather than during adulthood (Hall et al., 2004; Foote et al., 2010), as is the case in other vertebrates (Frenck et al., 1998; Rufer et al., 1998; Zeichner et al., 1999; Friedrich et al., 2001). Additionally, Haussmann et al. (2003) showed a significant and positive relationship between telomere length and age in another long-lived seabird species, the Letch's storm petrel (Oceanodroma leucorhoa). Consequently, effect of age on telomere length appears to be more complex rather than a simple negative and constant decrease of telomere length with age. Furthermore, it has been reported that in several seabird species, blood level of POPs is unrelated to age in adult birds (Bustnes et al., 2003; Carravieri et al., 2014; Tartu et al., 2015b), and rather reaches a steady state of equilibrium once adult (Newton et al., 1981; Henriksen, 1995; Drouillard, 2001; Bustnes et al., 2003). Therefore, it is 
unlikely that the negative relationship between oxychlordane and telomere length originates from birds with high levels of oxychlordane being the oldest birds with the shortest telomeres. Previous studies have shown decreased antioxidant enzyme activity in relation to contaminants, such as in herring gulls (Larus argentatus), where chicks exposed to PCBs combined with dietary restrictions showed negative relationships between catalase, glutathione peroxidase and contaminant levels (Hegseth et al., 2011). Similarly, significant negative associations between oxychlordane, $p, p$-DDE, PCB-153 and superoxide dismutase enzyme in white-tailed eagle chicks have been reported (Sletten et al., 2016). Finally, a significant positive relationship between oxychlordane, PCBs and oxidative stress was found in a Svalbard population of adult kittiwakes (Lindsøe, 2012). Consequently, oxychlordane could be possibly involved in the generation of oxidative stress through an increase of ROS which are known to reduce telomere length (Von Zglinicki, 2002). As the nucleobase guanine is a major oxidation target for ROS, the (TTAGGG)n repeats, that constitute vertebrate telomeres, are particularly vulnerable to oxidative attacks (Wang et al., 2010). In our study, in vivo biomarkers of oxidative stress were not measured. Thus, further studies measuring at the same time POP levels, proxies of oxidative stress and telomere length are thus needed to test if oxidative stress induced by oxychlordane exposure could be linked to telomere attrition. Among other potential mechanisms, oxychlordane could induce a down-regulation of telomerase activity. Indeed, telomere integrity is largely maintained by a telomerase-based mechanism, in which the enzyme telomerase plays a key role by adding hexameric (TTAGGG) repeats to chromosome ends, partially compensating telomere shortening (Greider and Blackburn, 1989; Xin et al., 2008). However, this hypothesis seems unlikely since telomerase is generally inactivated in adult somatic cells of most studied species so far (Monaghan and Haussmann, 2006; Vleck et al., 2007; but see Hatakeyama et al., 2008). Consequently, telomerase down-regulation seems to be more a 
common feature of large and/or long-lived species (Gomes et al., 2011) rather than being specifically related to contamination levels.

Extensively used during $>35$ years as a pesticide, usage of chlordane, of which oxychlordane is a major metabolite, tended to decrease in the 80 s (U.S. Department of Health and Human Services, 1994). Banned from use and listed as a legacy POP by the Stockholm convention since 2004, oxychlordane provided a clear diagnostic criterion related to the lethal poisoning in several bird species (Blus et al., 1983, 1985; Stickel et al., 1983; Okoniewski and Novesky, 1993; Stansley and Roscoe, 1999; Wiemeyer, 1996). Furthermore, in an experimental study where female rats were gavage with oxychlordane, high administrated doses $\left(10 \mathrm{mg} \cdot \mathrm{kg}^{-1}\right)$ revealed acute toxicity, characterized by feed refusal, rapid weight loss and thymic atrophy. At lower doses $\left(2.5 \mathrm{mg} \cdot \mathrm{kg}^{-1}\right)$, female rats showed signs of hepatic changes indicative of microsomal enzyme induction (Bondy et al., 2003). Finally, as previously mentioned, in glaucous gulls and in kittiwakes from Svalbard, oxychlordane has been associated with lower survival rates, especially in females (Erikstad et al., 2013; Goutte et al., 2015). In the present study, among legacy POPs, only oxychlordane was negatively associated with telomere length in females. Our results are thus consistent with the idea that oxychlordane is one of the most toxic POPs (Erikstad et al., 2013). Consequently, female kittiwakes' sensitivity to oxychlordane could affect telomere length, explaining the previously reported lower survival rate in highly contaminated female kittiwakes. On the other side, the lack of relationships between oxychlordane and telomere length in males suggest that the lowest survival rate of most oxychlordane contaminated birds is thus probably not mediated by telomere shortening in male kittiwakes.

This study is the first to report a significant and negative relationship between POPs and telomere length in wildlife and therefore partly fills the gap of knowledge about contaminants effect on telomere attrition. However, the present work has some limitations. First, we did not 
measure oxidative stress or other potential mechanisms. Thus, further studies measuring at the same time POP levels, proxies of oxidative stress and telomere length are thus needed to test if oxidative stress induced by oxychlordane exposure could be linked to telomere attrition. Secondly, among all tested contaminants only blood oxychlordane concentration was negatively associated with telomere length and even though several studies have reported that oxychlordane is highly toxic for birds, an experimental approach would enable to confirm the acute toxicity of this compound on telomere length through oxidative stress. Finally, our study was conducted on a limited number of individuals and to fully validate our finding, future studies investigating effects of POPs on telomere length should be conducted on a larger sample size and other species.

\section{Acknowledgements}

This project was supported by Institut Polaire Français (IPEV project 330 to O.Chastel, no. 2012 R03) and by Agence National de la Recherche (ANR project PolarTop to O.Chastel, no. ANR 10 CESA 0016) and by the Research Council of Norway (AVITOX project to J.O. Bustnes, no. 234423). P. Blévin was funded by a PhD grant from University of La Rochelle. This study was approved by the French and Norwegian Ethic committees and by the Governor of Svalbard. The authors thank Linda Hanssen, the staff of the NILU laboratory in Troms $\varnothing$ for their assistance during the POPs analysis, David Pinaud for statistical advices on bootstrap procedures and multiple testing and the two anonymous referees for their constructive comments that definitely improved the earlier version of the manuscript.

\section{References}

Angelier, F., Vleck, C.M., Holberton, R.L., Marra, P.P., 2013. Telomere length, non-breeding habitat and return rate in male American redstarts. Funct. Ecol. 27, 342-350.

Barrett, E.L.B., Burke, T.A., Hammers, M., Komdeur, J., Richardson, D.S., 2013. Telomere length and dynamics predict mortality in a wild longitudinal study. Mol. Ecol. 22, 249259. http://dx.doi.org/10.1111/mec.12110.

Bin, P., Leng, S.G., Cheng, J., Pan, Z.F., Duan, H.W., Dai, Y.F., Li, H.S., Niu, Y., Liu, Q.J., Liu, Q., 2010. Association between telomere length and occupational polycyclic aromatic hydrocarbons exposure. Zhonghua Yu Fang Yi Xue Za Zhi 44, 535-538. 
Bize, P., Criscuolo, F., Metcalfe, N.B., Nasir, L., Monaghan, P., 2009. Telomere dynamics rather than age predict life expectancy in the wild. Proc. R. Soc. B Biol. Sci. 276, 16791683. http://dx.doi.org/10.1098/rspb.2008.1817.

Blackburn, E.H., 1991. Structure and function of telomeres. Nature 350, 569-573.

Blus, L.J., Henny, C.J., Krynitsky, A.J., 1985. Organochlorine-induced mortality and residues in long-billed curlews from Oregon. Condor 87, 563-565.

Blus, L.J., Pattee, O.H., Henny, C.J., Prouty, R.M., 1983. First records of chlordane-related mortality in wild birds. J. Wildl. Manag. 47, 196-198.

Bondy, G., Armstrong, C., Coady, L., Doucet, J., Robertson, P., Feeley, M., Barker, M., 2003. Toxicity of the chlordane metabolite oxychlordane in female rats: clinical and histopathological changes. Food Chem. Toxicol. 41, 291-301.

Bustnes, J.O., Bakken, V., Skaare, J.U., Erikstad, K.E., 2003. Age and accumulation of persistent organochlorines: a study of arctic-breeding glaucous gulls (Larus hyperboreus). Environ. Toxicol. Chem. 22, 2173-2179.

Campisi, J., Kim, S.H., Lim, C.S., Rubio, M., 2001. Cellular senescence, cancer and aging: the telomere connection. Exp. Gerontol. 36, 1619-1637.

Carravieri, A., Bustamante, P., Tartu, S., Meillère, A., Labadie, P., Budzinski, H., Peluhet, L., Barbraud, C., Weimerskirch, H., Chastel, O., Cherel, Y., 2014. Wandering albatrosses document latitudinal variations in the transfer of persistent organic pollutants and mercury to Southern ocean predators. Environ. Sci. Technol. 48, 14746-14755.

Chernick, M.R., LaBudde, R.A., 2014. An Introduction to Bootstrap Methods With Applications to R. John Wiley \& Sons.

Costantini, D., Meillère, A., Carravieri, A., Lecomte, V., Sorci, G., Faivre, B., Weimerskirch, H., Bustamante, P., Labadie, P., Budzinski, H., Chastel, O., 2014. Oxidative stress in relation to reproduction, contaminants, gender and age in a long-lived seabird. Oecologia 175, 1107-1116. http://dx.doi.org/10.1007/s00442-014-2975-x.

Coulson, J.C., 2011. The Kittiwake. T \& AD Poyser. De Felice, B., Nappi, C., Zizolfi, B., Guida, M., Sardo, A.D.S., Bifulco, G., Guida, M., 2012. Telomere shortening in women resident close to waste landfill sites. Gene 500, 101-106.

Drouillard, K.G., 2001. Modeling the Toxicokinetics and Biomagnification of Polychlorinated Biphenyls (PCBs) in Birds. Univ Tromsö, Norway, Thesis.

Erikstad, K.E., Sandvik, H., Reiertsen, T.K., Bustnes, J.O., Strom, H., 2013. Persistent organic pollution in a high-Arctic top predator: sex-dependent thresholds in adult survival. Proc. R. Soc. B Biol. Sci. 280, 20131483. http://dx.doi.org/10.1098/rspb.2013.1483. 
Eshkoor, S.A., Jahanshiri, F., Ismail, P., Rahman, S.A.,Moin, S., Adon,M.Y., 2012. Association between telomere shortening and ageing during occupational exposure. J. Med. Biochem. 31, 211-216.

Fernie, K.J., Shutt, J.L., Mayne, G., Hoffman, D., Letcher, R.J., Drouillard, K.G., Ritchie, I.J., 2005. Exposure to polybrominated diphenyl ethers (PBDEs): changes in thyroid, vitamin A, glutathione homeostasis, and oxidative stress in American kestrels (Falco sparverius). Toxicol. Sci. 88, 375-383.

Finkel, T., Holbrook, N.J., 2000. Oxidants, oxidative stress and the biology of ageing. Nature 408, 239-247.

Foote, C.G., Daunt, F., González-Solís, J., Nasir, L., Phillips, R.A., Monaghan, P., 2010. Individual state and survival prospects: age, sex, and telomere length in a long-lived seabird. Behav. Ecol. 22, 156-161.

Frenck, R.W., Blackburn, E.H., Shannon, K.M., 1998. The rate of telomere sequence loss in human leukocytes varies with age. Proc. Natl. Acad. Sci. 95, 5607-5610.

Friedrich, U., Schwab, M., Griese, E.U., Fritz, P., Klotz, U., 2001. Telomeres in neonates: new insights in fetal hematopoiesis. Pediatr. Res. 49, 252-256.

Gabrielsen, G.W., Henriksen, E.O., 2001. Persistent organic pollutants in Arctic animals in the Barents Sea area and at Svalbard; levels and effects (review). Mem. Natl. Inst. Polar Res. Spec. Issue 54, 349-364.

Gomes, N., Ryder, O.A., Houck, M.L., Charter, S.J., Walker, W., Forsyth, N.R., Austad, S.N., Venditti, C., Pagel, M., Shay, J.W., 2011. Comparative biology of mammalian telomeres: hypotheses on ancestral states and the roles of telomeres in longevity determination. Aging Cell 10, 761-768.

Goutte, A., Angelier, F., Chastel, C.C., Trouvé, C., Moe, B., Bech, C., Gabrielsen, G.W., Chastel, O., 2010. Stress and the timing of breeding: glucocorticoid-luteinizing hormones relationships in an arctic seabird. Gen. Comp. Endocrinol. 169, 108-116.

Goutte, A., Barbraud, C., Herzke, D., Bustamante, P., Angelier, F., Tartu, S., Clément-Chastel, C., Moe, B., Bech, C., Gabrielsen, G.W., Bustnes, J.O., Chastel, O., 2015. Survival rate and breeding outputs in a high Arctic seabird exposed to legacy persistent organic pollutants and mercury. Environ. Pollut. 200, 1-9.

Graham, M.H., 2003. Confronting multicollinearity in ecological multiple regression. Ecology 84, 2809-2815.

Greider, C.W., Blackburn, E.H., 1989. A telomeric sequence in the RNA of Tetrahymena telomerase required for telomere repeat synthesis. Nature 337, 331-337. 
Hall, M.E., Nasir, L., Daunt, F., Gault, E.A., Croxall, J.P.,Wanless, S., Monaghan, P., 2004. Telomere loss in relation to age and early environment in long-lived birds. Proc. R. Soc. Lond. B Biol. Sci. 271, 1571-1576.

Hatakeyama, H., Nakamura, K.I., Izumiyama-Shimomura, N., Ishii, A., Tsuchida, S., Takubo, K., Ishikawa, N., 2008. The teleost Oryzias latipes shows telomere shortening with age despite considerable telomerase activity throughout life. Mech. Ageing Dev. 129, 550-557. Haussmann, M.F., Winkler, D.W., O'Reilly, K.M., Huntington, C.E., Nisbet, I.C., Vleck, C.M., 2003. Telomeres shorten more slowly in long-lived birds and mammals than in short-lived ones. Proc. R. Soc. Lond. B Biol. Sci. 270, 1387-1392.

Haussmann, M.F., Winkler, D.W., Vleck, C.M., 2005. Longer telomeres associated with higher survival in birds. Biol. Lett. 1, 212-214.

Haussmann, M.F., Vleck, C., 2002. Telomere length provides a new technique for aging animals. Oecologia 130, 325-328. http://dx.doi.org/10.1007/s00442-001-0827-y.

Hegseth, M.N., Camus, L., Gorbi, S., Regoli, F., Gabrielsen, G.W., 2011. Effects of exposure to halogenated organic compounds combined with dietary restrictions on the antioxidant defense system in herring gull chicks. Sci. Total Environ. 409, 2717-2724.

Heidinger, B.J., Blount, J.D., Boner, W., Griffiths, K., Metcalfe, N.B., Monaghan, P., 2012. Telomere length in early life predicts lifespan. Proc. Natl. Acad. Sci. 109, 1743-1748.

Henriksen, E.O., 1995. Levels and Congener Pattern of PCBs in Kittiwake, Rissa tridactyla, in Relation to Mobilization of Body lipids Associated with Reproduction Thesis Univ Tromsö, Norway.

Herzke, D., Nygård, T., Berger, U., Huber, S., Røv, N., 2009. Perfluorinated and other persistent halogenated organic compounds in European shag (Phalacrocorax aristotelis) and common eider (Somateria mollissima) from Norway: a suburban to remote pollutant gradient. Sci. Total Environ. 408, 340-348.

Houben, J.M.J., Moonen, H.J.J., van Schooten, F.J., Hageman, G.J., 2008. Telomere length assessment: biomarker of chronic oxidative stress? Free Radic. Biol. Med. 44, 235-246.

Hou, L., Wang, S., Dou, C., Zhang, X., Yu, Y., Zheng, Y., Avula, U., Hoxha, M., Díaz, A., McCracken, J., Barretta, F., Marinelli, B., Bertazzi, P.A., Schwartz, J., Baccarelli, A.A., 2012. Air pollution exposure and telomere length in highly exposed subjects in Beijing, China: a repeated-measure study. Environ. Int. 48, 71-77.

Hoxha, M., Dioni, L., Bonzini, M., Pesatori, A., Fustinoni, S., Cavallo, D., Carugno, M., Albetti, B., Marinelli, B., Schwartz, J., Bertazzi, P., Baccarelli, A., 2009. Association 
between leukocyte telomere shortening and exposure to traffic pollution: a cross-sectional study on traffic officers and indoor office workers. Environ. Health 8, 41.

Isaksson, C., 2010. Pollution and its impact on wild animals: a meta-analysis on oxidative stress. EcoHealth 7, 342-350. http://dx.doi.org/10.1007/s10393-010-0345-7.

Kimura, M., Stone, R.C., Hunt, S.C., Skurnick, J., Lu, X., Cao, X., Harley, C.B., Aviv, A., 2010. Measurement of telomere length by the Southern blot analysis of terminal restriction fragment lengths. Nat. Protoc. 5, 1596-1607.

Letcher, R.J., Bustnes, J.O., Dietz, R., Jenssen, B.M., Jørgensen, E.H., Sonne, C., Verreault, J., Vijayan, M.M., Gabrielsen, G.W., 2010. Exposure and effects assessment of persistent organohalogen contaminants in arctic wildlife and fish. Sci. Total Environ. 408, 2995 3043. http://dx.doi.org/10.1016/j.scitotenv.2009.10.038.

Li, H., Jönsson, B.A.G., Lindh, C.H., Albin, M., Broberg, K., 2011. N-nitrosamines are associated with shorter telomere length. Scand. J. Work. Environ. Health 316-324.

Lindsøe, L.M., 2012. Humoral Immunity and Oxidative Stress in Black-Legged Kittiwake (Rissa tridactyla) and Common Eider (Sommateria mollissima) from Svalbard - Related to Bio Accumulated Organochlorine Contaminants Master thesis Univ Oslo, Norway.

McCracken, J., Baccarelli, A., Hoxha, M., Dioni, L., Melly, S., Coull, B., Suh, E., Vokonas, P., Schwartz, J., 2010. Annual ambient black carbon associated with shorter telomeres in elderly men: veterans affairs normative aging study. Environ. Health Perspect. 118, 15641570 .

Meillère, A., Brischoux, F., Ribout, C., Angelier, F., 2015. Traffic noise exposure affects telomere length in nestling house sparrows. Biol. Lett. 11, 20150559.

Mizutani, Y., Tomita, N., Niizuma, Y., Yoda, K., 2013. Environmental perturbations influence telomere dynamics in long-lived birds in their natural habitat. Biol. Lett. 9, 20130511.

Monaghan, P., Haussmann, M.F., 2006. Do telomere dynamics link lifestyle and lifespan? Trends Ecol. Evolution 21, 47-53. http://dx.doi.org/10.1016/j.tree.2005.11.007.

Monaghan, P., Nager, R.G., 1997. Why don't birds lay more eggs? Trends Ecol. Evol. 12, 270274.

Newton, I., Bogan, J., Marquiss, M., 1981. Organochlorine contamination and age in sparrow hawks. Environ. Pollut. Ser. Ecol. Biol. 25, 155-160.

Nussey, D.H., Baird, D., Barrett, E., Boner,W., Fairlie, J., Gemmell, N., Hartmann, N., Horn, T., Haussmann, M., Olsson, M., Turbill, C., Verhulst, S., Zahn, S., Monaghan, P., 2014. Measuring telomere length and telomere dynamics in evolutionary biology and ecology. Methods Ecol. Evol. 5, 299-310. 
Okoniewski, J.C., Novesky, E., 1993. Bird poisonings with cyclodienes in suburbia: links to historic use on turf. J. Wildl. Manag. 57, 630-639.

Olovnikov, A.M., 1996. Telomeres, telomerase, and aging: origin of the theory. Exp. Gerontol. 31, 443-448. http://dx.doi.org/10.1016/0531-5565(96)00005-8.

Pavanello, S., Pesatori, A.C., Dioni, L., Hoxha, M., Bollati, V., Siwinska, E., Mielzyńska, D., Bolognesi, C., Bertazzi, P.A., Baccarelli, A., 2010. Shorter telomere length in peripheral blood lymphocytes of workers exposed to polycyclic aromatic hydrocarbons. Carcinogenesis 31, 216-221.

R Development Core Team, 2011. R: A language and environment for statistical computing. R Foundation for Statistical Computing, Vienna, Austria ISBN 3-900051-07-0. http://www.R-project.org.

Rigolin, G.M., Porta, M.D., Bugli, A.M., Castagnari, B., Mauro, E., Bragotti, L.Z., Ciccone, M., Cuneo, A., Castoldi, G., 2004. Flow cytometric detection of accelerated telomere shortening in myelodysplastic syndromes: correlations with aetiological and clinicalbiological findings. Eur. J. Haematol. 73, 351-358.

Rollison, D.E., Epling-Burnette, P.K., Park, J.Y., Lee, J.H., Park, H., Jonathan, K., Cole, A.L., Painter, J.S., Guerrier, M., Meléndez-Santiago, J., Fulp, W., Komrokji, R., Lancet, J., List, A.F., 2011. Telomere length in myelodysplastic syndromes. Leuk. Lymphoma 52, 15281536. http://dx.doi.org/10.3109/10428194.2011.568648.

Rufer, N., Dragowska, W., Thornbury, G., Roosnek, E., Lansdorp, P.M., 1998. Telomere length dynamics in human lymphocyte subpopulations measured by flow cytometry. Nat. Biotechnol. 16, 743-747.

Salomons, H.M., Mulder, G.A., van de Zande, L., Haussmann, M.F., Linskens, M.H.K., Verhulst, S., 2009. Telomere shortening and survival in free-living corvids. Proc. R. Soc. B Biol. Sci. 276, 3157-3165. http://dx.doi.org/10.1098/rspb.2009.0517.

Schultner, J., Moe, B., Chastel, O., Bech, C., Kitaysky, A.S., 2014a. Migration and stress during reproduction govern telomere dynamics in a seabird. Biol. Lett. 10, 20130889.

Schultner, J., Moe, B., Chastel, O., Tartu, S., Bech, C., Kitaysky, A.S., 2014b. Corticosterone mediates carry-over effects between breeding and migration in the kittiwake Rissa tridactyla. Mar. Ecol. Prog. Ser. 496, 125-133.

U.S. Department of Health and Human Services, 1994. Toxicological profile for chlordane (update). Agency for Toxic Substances and Disease Registry. TP-93/03. 
Shin, J.Y., Choi, Y.Y., Jeon, H.-S., Hwang, J.H., Kim, S.A., Kang, J.H., Chang, Y.S., Jacobs, D.R., Park, J.Y., Lee, D.H., 2010. Low-dose persistent organic pollutants increased telomere length in peripheral leukocytes of healthy Koreans. Mutagenesis 25, 511-516.

Sletten, S., Bourgeon, S., Bårdsen, B.J., Herzke, D., Criscuolo, F., Massemin, S., Zahn, S., Johnsen, T.V., Bustnes, J.O., 2016. Organohalogenated contaminants in white-tailed eagle (Haliaeetus albicilla) nestlings: an assessment of relationships to immunoglobulin levels, telomeres and oxidative stress. Sci. Total Environ. 539, 337-349.

Stansley,W., Roscoe, D.E., 1999. Chlordane poisoning of birds in New Jersey. USA. Environ. Toxicol. Chem. 18, 2095-2099.

Stickel, L.F., Stickel,W.H., Dyrland, R.A., Hughes, D.L., 1983. Oxychlordane, HCS-3260, and nonachlor in birds: lethal residues and loss rates. J. Toxicol. Environ. Health Part Curr. Issues 12, 611-622.

Tartu, S., Angelier, F., Bustnes, J.O., Moe, B., Hanssen, S.A., Herzke, D., Gabrielsen, G.W., Verboven, N., Verreault, J., Labadie, P., 2015a. Polychlorinated biphenyl exposure and corticosterone levels in seven polar seabird species. Environ. Pollut. 197, 173-180.

Tartu, S., Angelier, F., Wingfield, J.C., Bustamante, P., Labadie, P., Budzinski, H., Weimerskirch, H., Bustnes, J.O., Chastel, O., 2015b. Corticosterone, prolactin and egg neglect behavior in relation to mercury and legacy POPs in a long-lived Antarctic bird. Sci. Total Environ. 505, 180-188.

Tartu, S., Gabrielsen, G.W., Blévin, P., Ellis, H., Bustnes, J.O., Herzke, D., Chastel, O., 2014. Endocrine and fitness correlates of long-chain perfluorinated carboxylates exposure in Arctic breeding black-legged kittiwakes. Environ. Sci. Technol. 48, 13504-13510.

Tartu, S., Goutte, A., Bustamante, P., Angelier, F., Moe, B., Clément-Chastel, C., Bech, C., Gabrielsen, G.W., Bustnes, J.O., Chastel, O., 2013. To breed or not to breed: endocrine response to mercury contamination by an Arctic seabird. Biol. Lett. 9, 20130317.

Verboven, N., Verreault, J., Letcher, R.J., Gabrielsen, G.W., Evans, N.P., 2009. Differential investment in eggs by Arctic-breeding glaucous gulls (Larus hyperboreus) exposed to persistent organic pollutants. Auk 126, 123-133.

Vleck, C.M., Haussmann, M.F., Vleck, D., 2007. Avian senescence: underlying mechanisms. J. Ornithol. 148, 611-624.

Von Zglinicki, T., 2002. Oxidative stress shortens telomeres. Trends Biochem. Sci. 27, 339344.

Von Zglinicki, T., Pilger, R., Sitte, N., 2000. Accumulation of single-strand breaks is the major cause of telomere shortening in human fibroblasts. Free Radic. Biol. Med. 28, 64-74. 
Wang, Z., Rhee, D.B., Lu, J., Bohr, C.T., Zhou, F., Vallabhaneni, H., de Souza-Pinto, N.C., Liu, Y., 2010. Characterization of oxidative guanine damage and repair in mammalian telomeres. PLoS Genet. 6, e1000951.

Weimerskirch, H., Lallemand, J., Martin, J., 2005. Population sex ratio variation in a monogamous long-lived bird, the wandering albatross. J. Anim. Ecol. 74, 285-291.

Wiemeyer, S.N., 1996. Other organochlorine pesticides in birds. Environ. Contam. Wildl. Interpret. Tissue Conc. 99-115.

Wu, Y., Liu, Y., Ni, N., Bao, B., Zhang, C., Lu, L., 2012. High lead exposure is associated with telomere length shortening in Chinese battery manufacturing plant workers. Occup. Environ. Med. 69, 557-563.

Xin, H., Liu, D., Songyang, Z., 2008. The telosome/shelterin complex and its functions. Genome Biol. 9, 232.

Zeichner, S.L., Palumbo, P., Feng, Y., Xiao, X., Gee, D., Sleasman, J., Goodenow, M., Biggar, R., Dimitrov, D., 1999. Rapid telomere shortening in children. Blood 93, 2824-2830.

Zhang, X., Lin, S., Funk, W.E., Hou, L., 2013. Republished: environmental and occupational exposure to chemicals and telomere length in human studies. Postgrad. Med. J. 89, $722-$ 728. 
Table 1. Relationships between whole blood $\sum$ POPs, $\sum$ PCBs, OCPs and telomere length in male and female chick-rearing black-legged kittiwakes Rissa tridactyla from Kongsfjorden, Svalbard.

\begin{tabular}{|c|c|c|c|c|}
\hline Dependent variables & Independent variables & $d f$ & $F$ & P-value \\
\hline Telomere length & $\sum$ POPs* & 1,14 & 0.802 & 0.386 \\
\hline & $\sum \mathrm{PCBs}^{* *}$ & 1,14 & 0.833 & 0.377 \\
\hline & HCB & 1,14 & 0.534 & 0.477 \\
\hline & $p, p$ '-DDE & 1,14 & 0.066 & 0.801 \\
\hline & Oxychlordane & 1,14 & 5.343 & 0.037 \\
\hline & cis-nonachlor & 1,14 & 1.246 & 0.283 \\
\hline & trans-nonachlor & 1,14 & 1.301 & 0.273 \\
\hline \multirow[t]{7}{*}{ Telomere length } & $\sum$ POPs* & 1,20 & 0.394 & 0.537 \\
\hline & $\sum \mathrm{PCBs}^{* *}$ & 1,20 & 0.114 & 0.740 \\
\hline & $\mathrm{HCB}$ & 1,20 & 0.002 & 0.967 \\
\hline & $p, p$ '-DDE & 1,20 & 1.351 & 0.259 \\
\hline & Oxychlordane & 1,20 & 0.025 & 0.876 \\
\hline & cis-nonachlor & 1,20 & 0.077 & 0.785 \\
\hline & trans-nonachlor & 1,20 & 0.922 & 0.348 \\
\hline
\end{tabular}

Significant variables are in bold.

* $\sum$ POPs: CB-99, $-118,-138,-153,-180,-183,-187, \mathrm{HCB}, p, p$ '-DDE, oxychlordane, trans- and cis-nonachlor

$* * \Sigma$ PCBs: CB-99, $-118,-138,-153,-180,-183,-187$ 


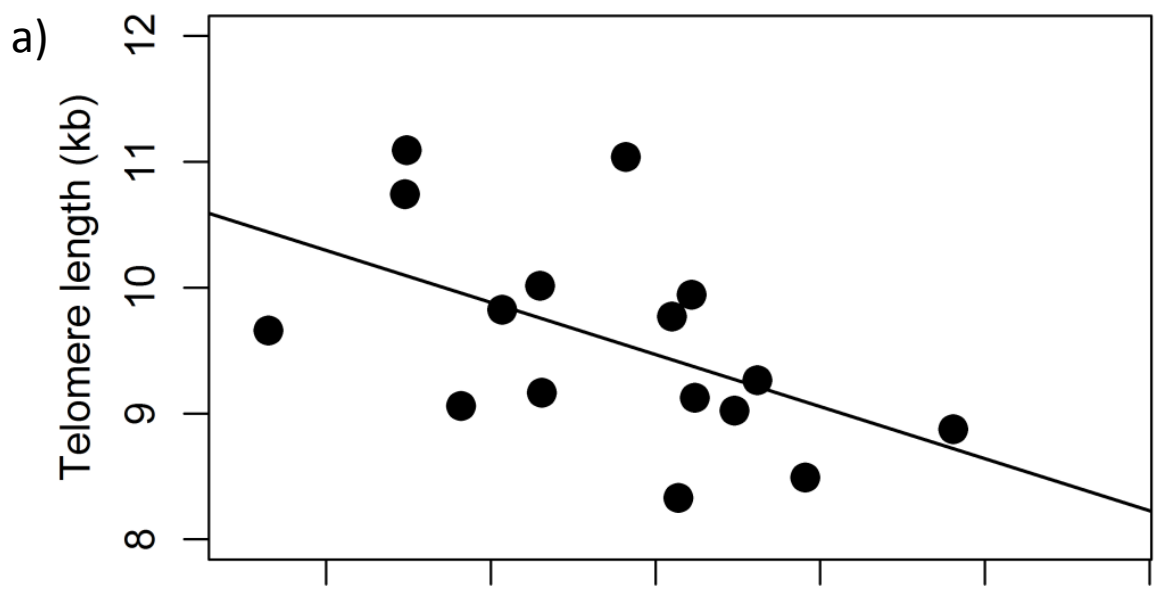

b)

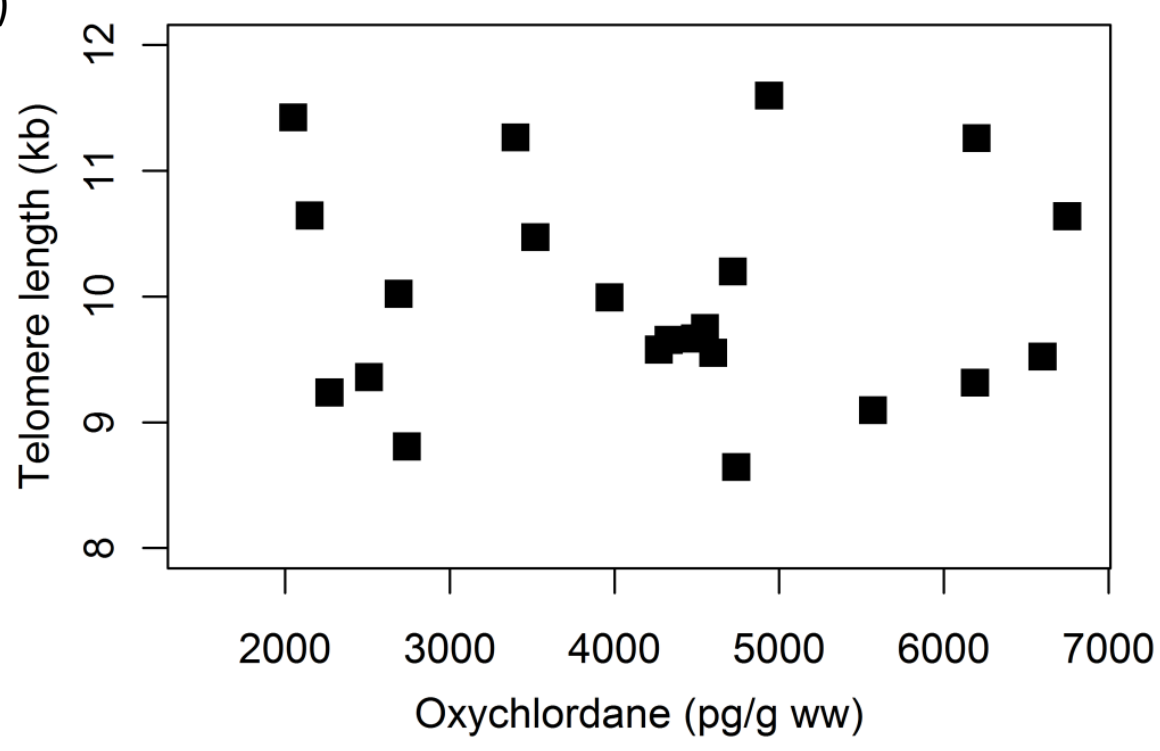

Figure 1. Relationships between telomere length and whole blood oxychlordane concentrations in female (a) and male (b) chick-rearing black-legged kittiwakes Rissa tridactyla from Kongsfjorden, Svalbard. 


\section{Supplementary material}

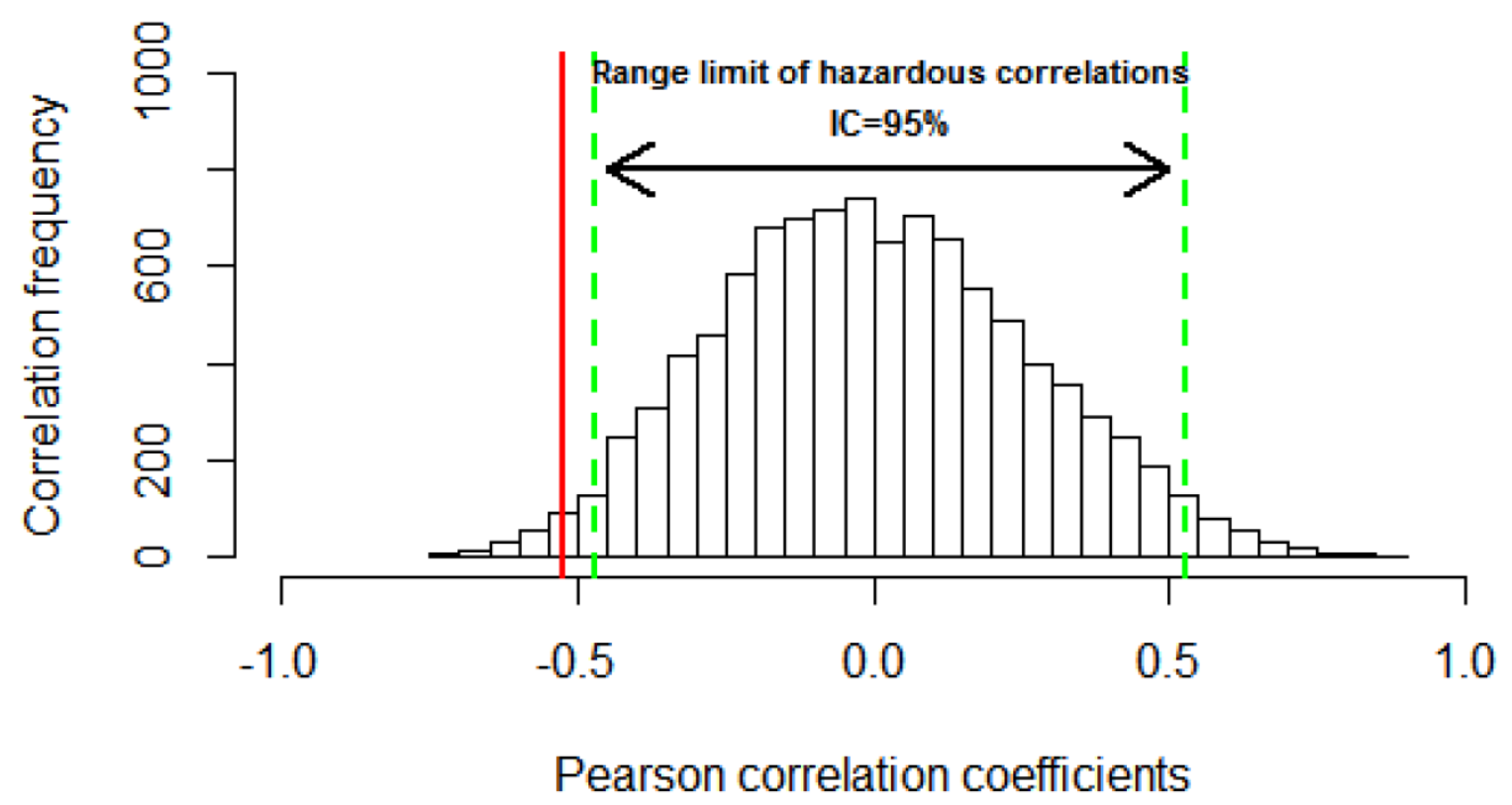

Fig. S1. Bootstrapping from the dataset of the significant relationship between oxychlordane and telomere length for female kittiwakes (10 000 iterations). The green axes represent the range limit of hazardous correlations with an interval confidence (IC) of 95\%. The red axis corresponds to the Pearson correlation coefficient $(r=-0.53)$ between oxychlordane and telomere length in female kittiwakes. The correlation between oxychlordane and telomere length is outside the range limit of hazardous correlations ( $\mathrm{IC}=95 \%$ ) testifying that the significant and negative relationship between oxychlordane and telomere length in female kittiwakes is consistent and corroborates our result. 